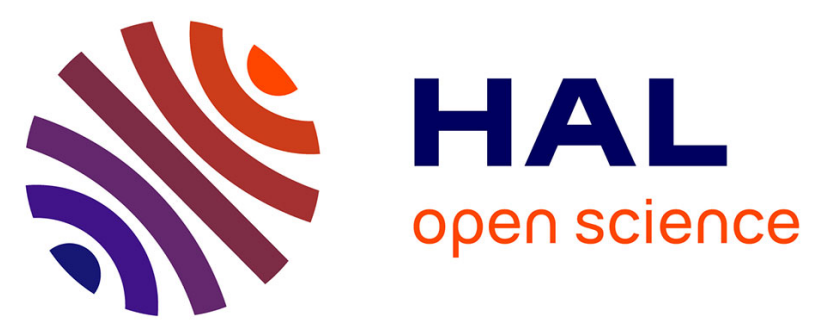

\title{
Oxidative solution polymerization of aniline hydrochloride onto electrospun nanofibers mats of polylactic acid: Preparation method and characterization
}

Mazen Al-Jallad, Yomen Atassi, Eskandar Mounif, Matthieu Aressy, Abbas

Tcharkhtchi

\section{To cite this version:}

Mazen Al-Jallad, Yomen Atassi, Eskandar Mounif, Matthieu Aressy, Abbas Tcharkhtchi. Oxidative solution polymerization of aniline hydrochloride onto electrospun nanofibers mats of polylactic acid: Preparation method and characterization. Journal of Applied Polymer Science, 2014, 132, pp.41618 (1-7). 10.1002/app.41618 . hal-01108954

\author{
HAL Id: hal-01108954 \\ https://hal.science/hal-01108954
}

Submitted on 2 Feb 2015

HAL is a multi-disciplinary open access archive for the deposit and dissemination of scientific research documents, whether they are published or not. The documents may come from teaching and research institutions in France or abroad, or from public or private research centers.
L'archive ouverte pluridisciplinaire HAL, est destinée au dépôt et à la diffusion de documents scientifiques de niveau recherche, publiés ou non, émanant des établissements d'enseignement et de recherche français ou étrangers, des laboratoires publics ou privés. 


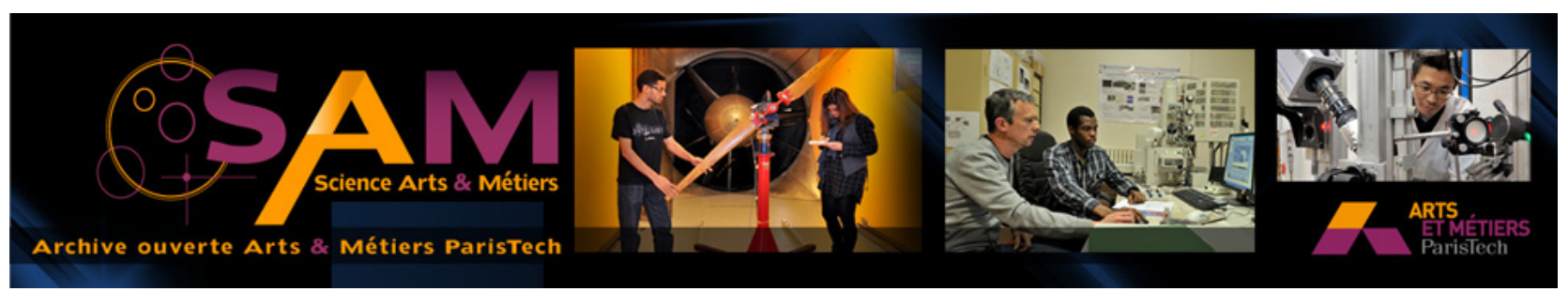

\section{Science Arts \& Métiers (SAM)}

is an open access repository that collects the work of Arts et Métiers ParisTech researchers and makes it freely available over the web where possible.

This is an author-deposited version published in: http://sam.ensam.eu Handle ID: .http://hdl.handle.net/10985/9267

\section{To cite this version :}

Mazen AL-JALLAD, Atassi YOMEN, Eskandar MOUNIF, Matthieu ARESSY, Abbas TCHARKHTCHI - Oxidative solution polymerization of aniline hydrochloride onto electrospun nanofibers mats of polylactic acid: Preparation method and characterization - Journal of Applied Polymer Science - Vol. 132, p.41618 (1-7) - 2014 


\title{
Oxidative solution polymerization of aniline hydrochloride onto electrospun nanofibers mats of polylactic acid: Preparation method and characterization
}

\author{
Mazen Al-Jallad, ${ }^{1}$ Yomen Atassi, ${ }^{1}$ Eskandar Mounif, ${ }^{1}$ Matthieu Aressy, ${ }^{2}$ Abbas Tcharkhtchi ${ }^{2}$ \\ ${ }^{1}$ Physics Department, Higher Institute for Applied Science and Technology, Damascus, Syria \\ ²aboratoire PIMM, UMR 8006 CNRS, Arts et Métiers ParisTech, Paris 75013, France \\ Correspondence to: Y. Atassi (E-mail: yomen.atassi@hiast.edu.sy)
}

\begin{abstract}
In this work, we present the preparation of polylactic acid (PLLA)/polyaniline (PANI) conductive composite nanofibers mats. They are prepared by bulk oxidative solution polymerization of PANI onto electrospun non-woven fibers mats of PLLA. The PANI ratio in the composite is about 70\%w/w. Scanning electron microscopy (SEM) shows that PLLA nanofibers are randomly oriented, beads free with diameters of $186 \pm 85 \mathrm{~nm}$, The PLLA/PANI composite nanofibers diameter values are 518 $\pm 128 \mathrm{~nm}$ with a good adherence between PANI and PLLA nanofibers. DSC and XRD measurements reveal an amorphous structure of the electrospun PLLA fibers due to the rapid evaporization of the solvent. FTIR and UV-vis spectra reflect good mutual interactions between PANI and PLLA chains. The DC-conductivities $\left(\sigma=0.07-0.13 \mathrm{~S} . \mathrm{cm}^{-1}\right)$ far better than other published ones for similar composites prepared by bulk oxidative solution polymerization of PANI onto other electrospun nanofiber mats or with electrospun nanofibers from a solution mixture of PLLA and PANI.
\end{abstract}

KEYWORDS: composites; conducting polymers; electrospinning; nanostructured polymers; sensors and actuators

\section{INTRODUCTION}

In recent years, conducting polymers have received important attention because of their potential applications in chemical and biological sensors, electronic devices, batteries, supercapacitors, and solar cells..., due to their remarkable physical and electrical properties such as low operating temperature, low cost, flexibility, and moderate processibility. ${ }^{1-5}$ Polyaniline (PANI) is one of the most studied electrically conductive polymers and it was an attractive choice for researchers to develop many techniques to produce PANI nanostructures especially nanofibers. ${ }^{6-9}$ PANI is relatively more difficult to process compared to other polymers as it has a fairly rigid backbone due to the high aromaticity and as there are very few good solvents to dissolve it, so the elasticity of its solutions is generally insufficient to be electrospun directly into nanofibers. ${ }^{10}$ To overcome this obstacle many approaches have been proposed to prepare PANI nanofibers, such as seeding polymerization, ${ }^{11-13}$ interfacial polymerisation, ${ }^{14-16}$ electrospinning PANI blends with more flexible, high molecular weight polymers that serve as processing aids, ${ }^{6,10,17,18}$ and coating PANI onto a non-conducting nanofiber substrates using bulk oxidative solution polymerization process. ${ }^{19-22}$
On the other hand, polylactic acid (PLLA) is biodegradable and biocompatible. It presents good thermoplastic processability. Because of its biocompatibility, it's used as scaffolds for tissue engineering and a substrate for implant devices. Recently, it has been used for the preparation of conducting nanofibers in combination with PANI for sensors and tissue engineering applications by electrospinning a mixture of the two polymers solutions. ${ }^{23,24}$

In this study, we present the preparation of PLLA/PANI composite nanofibers mats by bulk oxidative solution polymerization of aniline hydrochloride onto electrospun PLLA nanofibers mats. To the best of our knowledge, this is the first preparation of PLLA/PANI composite nanofibers mats by this method. This work is a new approach to realize a good intercalation of PANI molecules with the PLLA nanofibers to form composite mats with promising electrical conductivities to be used in chemical sensors or as scaffolds for tissue engineering.

\section{EXPERIMENTAL}

Reagents and Chemicals

PLLA $\left(M_{w}=150,000 \mathrm{~g} / \mathrm{mol}\right)$ from NatureWorks was kindly offered by ENSAM/PIMM laboratory (Paris-France). Anilinium 
chloride monomer, tetra n-butyl ammonium bromide (TBAB), ammonium peroxydisulfate $\left[\left(\mathrm{NH}_{4}\right)_{2} \mathrm{~S}_{2} \mathrm{O}_{8}\right.$, APS $]$, dichloromethane, hydrochloric acid and acetone, all of analytical reagent grade, were purchased from Merck. Chemicals were used as received without further purifications.

\section{Electrospining of PLLA}

Electrospinning solution of PLLA with concentration of 6 wt \% was prepared by dissolving PLLA granules in dichloromethane under magnetic stirring for $5 \mathrm{~h}, 1$ wt $\%$ of TBAB was added as an electrolyte to enhance the conductivity of the electrospun solution. The electrical conductivity of spinable PLLA solution was $2 \mu \mathrm{S} \mathrm{cm}^{-1}$ without $\mathrm{TBAB}$ and $380 \mu \mathrm{S} \mathrm{cm} \mathrm{cm}^{-1}$ with $1 \mathrm{wt} \%$ $\mathrm{TBAB}$ at $24^{\circ} \mathrm{C}$. Polymer solution was added to $10 \mathrm{~mL}$ glass syringe with hypodermic needle used as nozzle. The inner and outer diameter of the needle is 0.6 and $0.8 \mathrm{~mm}$, respectively. The flow of the polymer solution was controlled using a programmable syringe pump (TOP-5300, Japan). The high-voltage power supply was an ES813-D50.1 Dual output: 0 to $\pm 50 \mathrm{kV} / 1$ $\mathrm{mA}$ Electrostatic/HV Generator (Rolla, USA). The collector was a sheet of aluminum $(0.4 \times 25 \times 40 \mathrm{~cm})$ covered with an aluminum foil.

The solution feed rate was kept at $1 \mathrm{~mL} \mathrm{~h}^{-1}$ and the distance between the collector and the needle tip was maintained at $13 \mathrm{~cm}$.

As the electric field increased beyond $20 \mathrm{kV}$, the surface tension of the polymer solution was overcome by the electric force and the Taylor cone was initiated. A stable jet began to form a white nanofibers adhered smoothly to the aluminum foil collector. The voltage was kept in the range $20-22 \mathrm{kV}$ during the experiments. The experimental temperature inside the electrospinning chamber was $22 \pm 2^{\circ} \mathrm{C}$, and the relative humidity was maintained between 40 and $50 \%$ to have a good evaporation of the solvent. The duration of each electrospinning process was $1 \mathrm{~h}$.

The as-spun fibers were left on the aluminum foil inside the electrospinning chamber for at least $24 \mathrm{~h}$ at the room temperature and at about $45 \%$ relative humidity to complete the volatilization of dichloromethane. Then they were peeled off from the aluminum foil for further experiments.

\section{Preparation of PLLA/PANI Composite Nanofiber Mats}

The PLLA nanofibers mat had a circular shape with a diameter of about $15 \mathrm{~cm}$ and a thickness of approximately $0.1 \mathrm{~mm}$. PLLA/ PANI composite nanofiber mat was produced using the oxidative solution polymerization process. Typically $(1.295 \mathrm{~g}, 10 \mathrm{mmol})$ of aniline hydrochloride was dissolved in $25 \mathrm{~mL}$ of deionized water with ultrasonication aid. Ammonium peroxydisulfate (APS) (2.855 g, $12.5 \mathrm{mmol}$ ) was dissolved in $25 \mathrm{~mL}$ of deionized water using magnetic stirring. Both solutions were kept for $1 \mathrm{~h}$ at room temperature $\left(\sim 20-24^{\circ} \mathrm{C}\right)$. PLLA nanofibers mat was then immersed into the aniline hydrochloride solution under the ultrasonic stirring for $30 \mathrm{~min}$. When the PLLA nanofibers mat is saturated with aniline solution, the APS solution is then added dropwise to the above mixture always under ultrasonic stirring for another $30 \mathrm{~min}$. The polymerization reaction begins as the first drop of APS solution is added, and the aniline monomer is oxidized with APS and doped with hydrochloride acid. The mixture was left for $5 \mathrm{~h}$ to insure that most of aniline monomers had been consumed and the polymerization reaction was almost finished. Next, the film was washed repeatedly with deionized water and acetone until the acetone washings were colorless, then washed three times with $50 \mathrm{~mL}$ of $0.2 \mathrm{M} \mathrm{HCl}$, and similarly with acetone. Finally, the nanofiber mats were dried in a desiccator at $40^{\circ} \mathrm{C}$ and stored in a closed vessel in the dark.

\section{Characterization}

PLLA and PLLA/PANI Composite Nanofiber Mats Morphology. The nanofibers morphology was analyzed using Tescan Vega-II XMU5136 variable pressure scanning electron microscopy (SEM).

The nanofiber mats thickness was measured using a digital micrometer (Mitutoyo CLM1).

X-ray Diffraction (XRD) Measurements. XRD patterns were performed with PHILIPS-PW3710X-RAY diffractometer operating at $60 \mathrm{kV}$ using $\mathrm{Cu}-\mathrm{K}_{\alpha}$ radiation $(\lambda=0.154 \mathrm{~nm})$. X-ray diffractograms were recorded in the $2 \theta$ range: $5^{\circ}-60^{\circ}$.

Differential Scanning Calorimetry (DSC). DSC analyses were carried out with a computerized SETARAM-INSTRUMENTATION TGA-DSC. Samples were heated to $200^{\circ} \mathrm{C}$ at a ramping rate of $10^{\circ} \mathrm{C} / \mathrm{min}$ in nitrogen atmosphere. Crystallinity of the PLLA fiber films was investigated according to following equation: ${ }^{25}$

$$
\text { Crystallinity }(\%)=\frac{\Delta H_{m}-\Delta H_{\mathrm{cc}}}{\Delta H_{m}^{0} \times C}
$$

where $\Delta H_{m}$ and $\Delta H_{m}^{0}$ are the endothermic enthalpy of the samples and that of $100 \%$ crystallized PLLA $\left(\Delta H_{m}^{0}=93 \mathrm{~J} / \mathrm{mol}\right.$ respectively. ${ }^{25} \Delta H_{\mathrm{cc}}$ is the enthalpy of cold crystallization. $C$ is the PLLA mass percentage $(\mathrm{m} \%)$ in the tested sample.

FTIR Spectroscopy. FTIR spectra were recorded by BRUKERVECTOR22 FTIR spectrophotometer. Samples of PLLA nanofiber mats and PLLA/PANI composite nanofiber mats were fixed on the support directly in the path of the optical beam. PANI powder was mixed with $\mathrm{KBr}$ and pressed in pellets. All spectra were corrected for the presence of moisture and carbon dioxide in the optical pathway.

UV-Vis Spectroscopy. UV-Vis spectra were recorded by JASCO V-350 UV-vis spectrophotometer in a wavelength range of 3001100 nm. Samples of PLLA nanofiber mats and PLLA/PANI composite nanofiber mats were held perpendicularly to the path of the beam. PANI powder was dissolved in dimethylformamide (DMF) in a quartz cellule. All spectra were corrected for the presence of moisture and carbon dioxide.

DC-Electrical Conductivity. DC-conductivity $(\sigma)$ was performed by four-probe technique using KEITHELY-220 programmable Current Source and KEITHELY-617 programmable electrometer. PLLA/PANI composite nanofiber mats were tested using four-probe homemade device consisting of four parallel platinum wires of $0.4-\mathrm{mm}$ diameter positioned $2 \mathrm{~mm}$ away from each other. The contact length for each probe was $2.3 \mathrm{~cm}$ as shown in Figure 1.

$\sigma$ was calculated using Van der Pauw relation $\sigma=\frac{d}{t \times w} \frac{I}{V}$, where $d$ is the distance between the electrodes $(\mathrm{cm}), t$ and $\mathrm{w}$ are the sample's thickness and width respectively $(\mathrm{cm})$. 


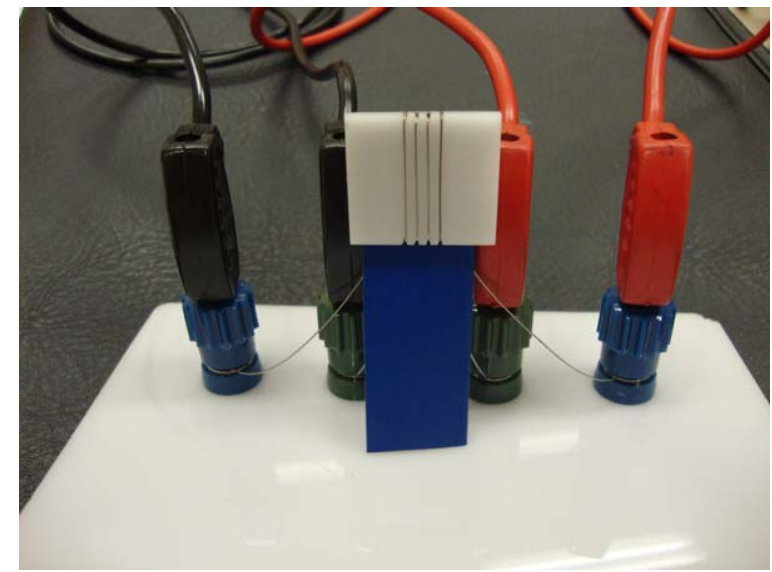

Figure 1. Photo of four-probe homemade device. [Color figure can be viewed in the online issue, which is available at wileyonlinelibrary.com.]

\section{RESULTS AND DISCUSSION}

\section{Morphology of the Composite Nanofiber Mats}

The peeled nanofiber mats of PLLA have a smooth and homogeneous surface as shown in Figure 2(a) with circular shape of about $15 \mathrm{~cm}$ diameter and about $0.1-\mathrm{mm}$ thickness with good mechanical toughness and high flexibility.

SEM micrographs [Figure 3(a-d)] show that PLLA nanofibers are smooth and hollow, as they are very transparent with very thin nanofibers walls. PLLA fibers have a statistical distribution of diameters with values of $186 \pm 85 \mathrm{~nm}$ and they are beads free.

The surface of nanofiber mats becomes rough with less elasticity. The mat diameter shrunk to about $10 \mathrm{~cm}$ and the thickness increased to about $0.2 \mathrm{~mm}$. The dark green color of the composite fiber mat indicated that PANI is in its emeraldine conductive form as shown in Figure 2(b).

SEM micrographs [Figure 3(e,f)] revealed that PANI polymer shields homogeneously the PLLA nanofiber with some aggregations of PANI adhered to the composite fiber surface. SEM micrographs [Figure $3(\mathrm{~g}, \mathrm{~h})$ ] of the cross section of PLLA/PANI composite nanofiber mat show that all the hollow PLLA nanofibers were shielded with PANI. This indicates that the anilinium chloride monomer was very well penetrated inside the mat before the beginning of the polymerization process by virtue of ultrasound stirring and indicate also the good distribution of the APS oxidant (dropwise added) under ultrasound stirring. So, this allowed to the polymerization process to proceed homogeneously in all parts of the mat. The diameter values of PLLA/PANI nanofibers are also statistical with values of $518 \pm 128 \mathrm{~nm}$.

\section{DSC Characterization}

DSC was employed to characterize thermal properties of PLLA nanofiber mats and PLLA/PANI composite nanofiber mats. For all composite fiber mats prepared in this work, the PANI content was about $70 \% \mathrm{w} / \mathrm{w}$.

From Figure 4(a), the glass transition $\left(T_{g}\right)$ temperature was found at $53.8^{\circ} \mathrm{C}$ followed by a distinctive endothermic aging peak at about $62.4^{\circ} \mathrm{C}$. A cold crystallization exothermic peak $\left(T_{\mathrm{cc}}\right)$ was observed at $90^{\circ} \mathrm{C}$ and a sharp melting peak $\left(T_{m}\right)$ at $167^{\circ} \mathrm{C} .^{6,26,27}$ Integrating the two peaks $\left(T_{\mathrm{cc}}\right)$ and $\left(T_{m}\right)$ of PLLA nanofiber mat showed that they have the same absolute values ( $\Delta H_{m} \approx \Delta H_{\mathrm{cc}}=46 \mathrm{~J} / \mathrm{mol}$ ) which means that the melting phenomena that follows the cold crystallization concerned only the PLLA crystal phase developed during the heating scan. This indicates that the electrospun PLLA nanofibers were completely amorphous as it's predicted elsewhere by Gualandi et al. ${ }^{28}$

As for PLLA/PANI composite nanofiber mat DSC curve, it showed [Figure 4(b)] a small shift in temperatures values mentioned above, where $T_{g}$ was found at $55.5^{\circ} \mathrm{C}$ followed by aging peak at $76.7^{\circ} \mathrm{C}$. $T_{\mathrm{cc}}$ was mounted up to $104^{\circ} \mathrm{C}$ and $T_{m}$ was shifted to $168.5^{\circ} \mathrm{C}$. The aging peak of PANI was not observed in this spectrum because it is out of the heating range (250$\left.260^{\circ} \mathrm{C}\right) .^{29}$ One can attribute these shifts in temperatures positions to the mutual interactions between PLLA and PANI chains which create intermolecular bonds like Van der Waals bonds and hydrogen bonds between these molecules.

\section{FTIR Spectra}

From Figure 5(a) it can be seen the eight main characteristic peaks of PLLA which were located at 3495, 2970, 2882, 1755, $1456,1365,1196,1103 \mathrm{~cm}^{-1}$. These peaks were assigned as follows: the weak peak at $3495 \mathrm{~cm}^{-1}$ is assigned to $\mathrm{O}-\mathrm{H}$ stretching vibration. The bands located at $2970 \mathrm{~cm}^{-1}$ and $1456 \mathrm{~cm}^{-1}$ were assigned to $\mathrm{C}-\mathrm{H}$ stretching vibration and $-\mathrm{CH}(\mathrm{CH} 3)$
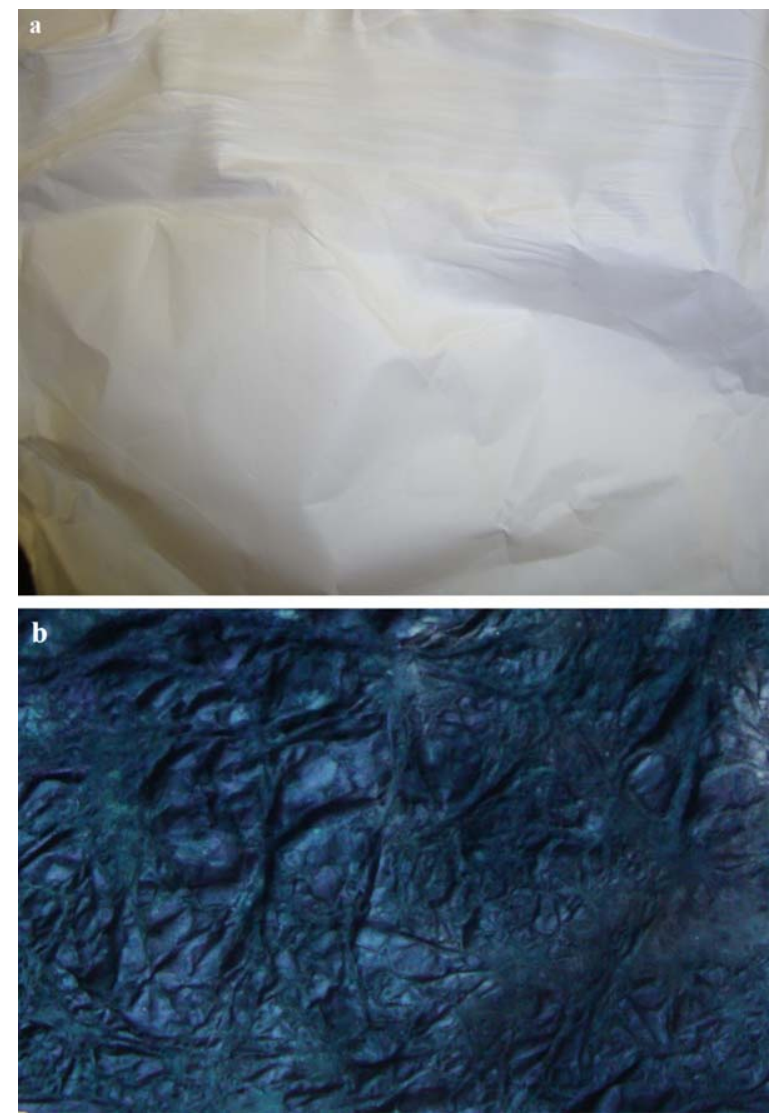

Figure 2. Photos of (a) PLLA nanofiber non-woven mat, (b) PLLA/PANI composite nanofiber non-woven mat. [Color figure can be viewed in the online issue, which is available at wileyonlinelibrary.com.] 

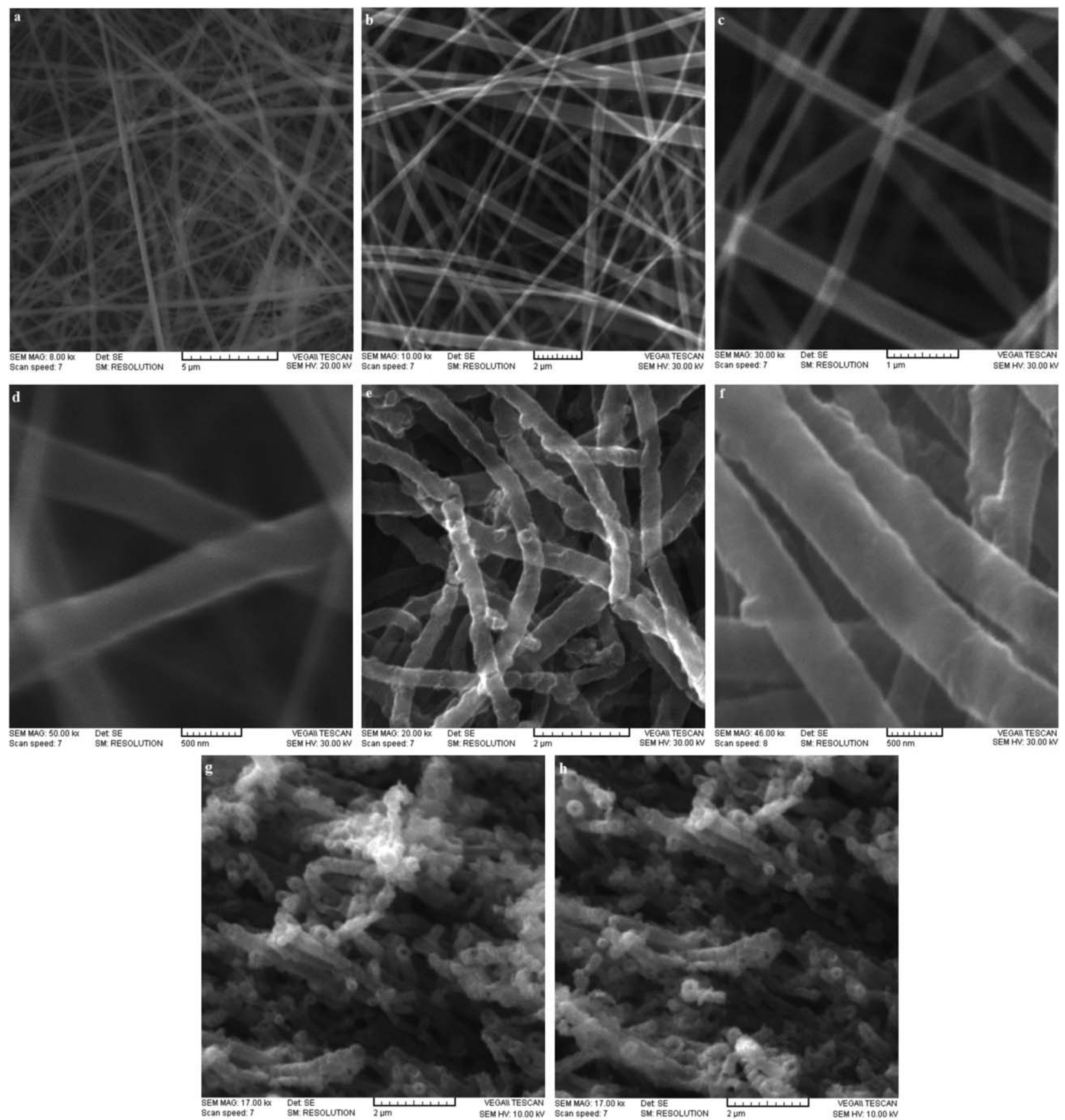

Figure 3. SEM micrographs of: PLLA nanofiber mat (a) without coating, (b-d) with graphite coating, (e, f) PLLA/PANI composite nanofiber mat and $(\mathrm{g}, \mathrm{h})$ cross section of PLLA/PANI composite nanofiber mat after immersing it in liquid nitrogen (SEM micrographs of composite are without coating).

bend vibration. The characteristic peak of $-\mathrm{CH}_{3}$ bending was located at $1365 \mathrm{~cm}^{-1}$. The weak shoulder at $2882 \mathrm{~cm}^{-1}$ was assigned to $-\mathrm{CH}_{2}$ stretching vibration. The peak at $1755 \mathrm{~cm}^{-1}$ was assigned to $\mathrm{C}=\mathrm{O}$ stretching vibration and the two peaks at 1196 and $1103 \mathrm{~cm}^{-1}$ were attributed to $\mathrm{C}-\mathrm{O}$ stretching vibration. $^{25,30,31}$

For PANI powder FT-IR spectrum, there are seven characteristic peaks situated at $3230,1566,1478,1300,1240,1135,804 \mathrm{~cm}^{-1}$ [Figure 5(b)]. The weak and broad band at $3230 \mathrm{~cm}^{-1}$ is assigned to the free $\mathrm{N}-\mathrm{H}$ stretching vibration of secondary amines.
The peak at $1566 \mathrm{~cm}^{-1}$ corresponds to the $\mathrm{C}=\mathrm{C}$ stretching of quinonoid rings, while the peak at $1478 \mathrm{~cm}^{-1}$ is assigned to $\mathrm{C}=\mathrm{C}$ stretching of benzenoid rings. The peaks at $1300 \mathrm{~cm}^{-1}$ and $1240 \mathrm{~cm}^{-1}$ are assigned to $\mathrm{C}-\mathrm{N}$ and $\mathrm{C}-\mathrm{N}^{+}$stretching vibration respectively. The strong peak centered at $1135 \mathrm{~cm}^{-1}$ is assigned to the vibration mode of $\mathrm{N}^{+}=\mathrm{C}$. The peak at 804 $\mathrm{cm}^{-1}$ is characterized to the aromatic $\mathrm{C}-\mathrm{H}$ out-of-plane bending vibration. ${ }^{32-35}$

Figure 5(c) shows the FT-IR spectrum of PLLA/PANI composite nanofiber mat. It combines the main characteristic peaks of PLLA and PANI. There is a slight deviation in peaks positions 


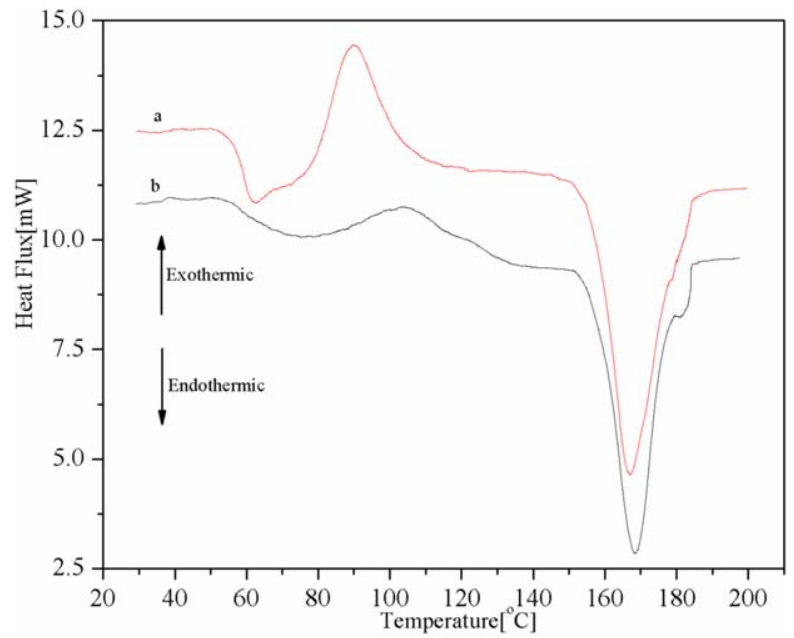

Figure 4. DSC analysis of (a) PLLA nanofiber mat and (b) PLLA/PANI composite nanofiber mat. [Color figure can be viewed in the online issue, which is available at wileyonlinelibrary.com.]

with a red shift which reveals the mutual interaction between PLLA and PANI chains in the composite nanofiber and reflects the existence of intermolecular bonds between the PLLA and PANI chains.

\section{XRD Measurements}

Figure 6(a) shows no peaks for PLLA nanofibers over all the scanning range with an expressive amorphous halo around $10^{\circ}$, referring to their completely amorphous structure as most of PLLA electrospun nanofibers. ${ }^{28,36,37}$ This XRD result is in accordance with the results obtained from DSC measurements which proves that there is no crystalline phase in these fibers. During the electrospinning process the solvent evaporizes quickly and since PLLA crystallizes slowly compared to other conventional thermoplastic polymers, ${ }^{38}$ polymer chains don't have enough time to be arranged in a crystalline structure, so PLLA crystallization is inhibited.

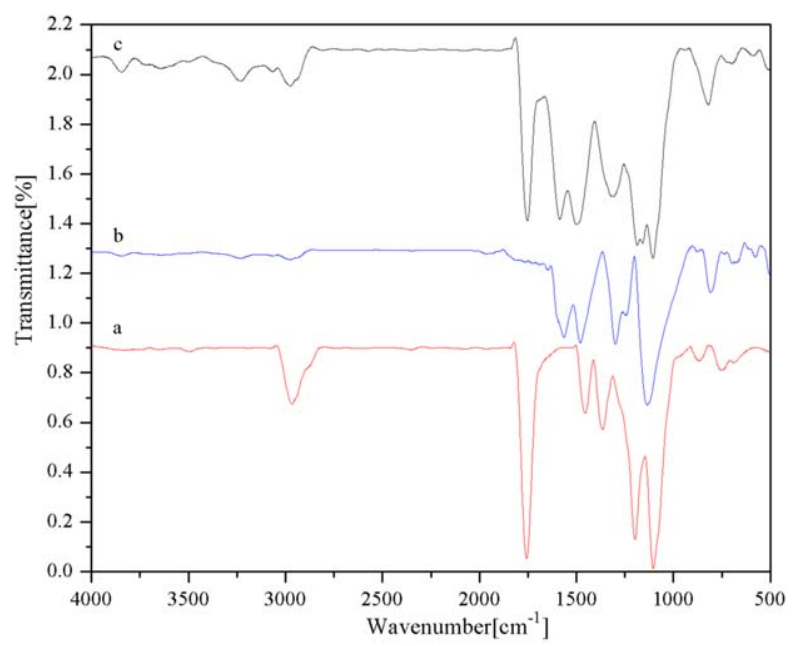

Figure 5. FT-IR spectra of (a) PLLA nanofiber mat, (b) PANI powder and (c) PLLA/PANI composite nanofiber mat. [Color figure can be viewed in the online issue, which is available at wileyonlinelibrary.com.]

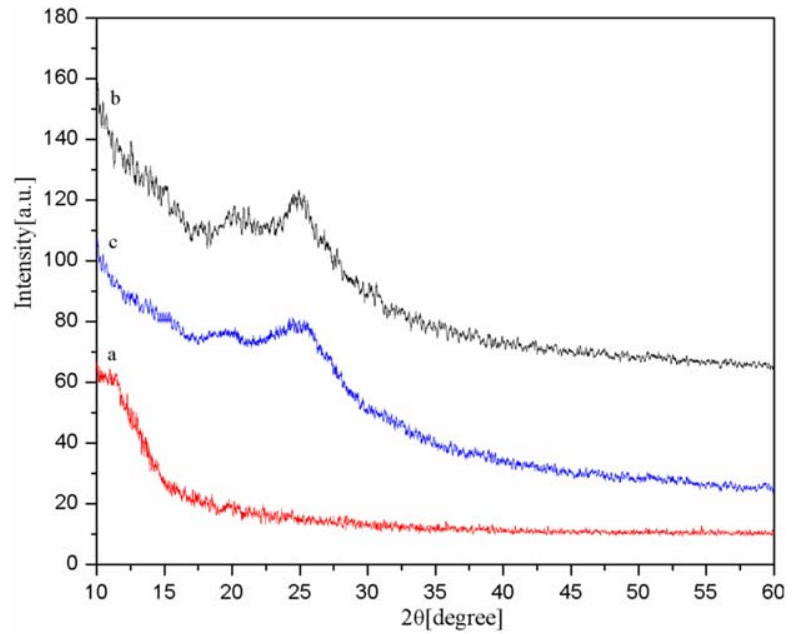

Figure 6. X-ray diffractograms of (a) PLLA nanofiber mat, (b) PANI powder and (c) PLLA/PANI composite nanofiber mat. [Color figure can be viewed in the online issue, which is available at wileyonlinelibrary.com.]

Two broad peaks appear in PANI powder spectrum [Figure 6(b) ], centered at $2 \theta=20^{\circ}$ and $25^{\circ}$ ascribed respectively to periodicity parallel and periodicity perpendicular to the polymer chain, showing that the resulting PANI is amorphous. $^{21,39-41}$

X-ray diffractogram of PLLA/PANI composite nanofiber [Figure 6(c)] is almost identical to PANI spectrum but with weak peaks intensities. One can deduce that the presence of PLLA nanofiber scaffold during the oxidative solution polymerization of PANI didn't affect the dominant tendency to form an amorphous structure for this polymer.

\section{UV-Vis Spectroscopy}

Figure 7(a) presents the UV-vis spectrum of PLLA. No characteristic bands appear in this spectrum with slight decrease in absorption intensity. PLLA fibers can be considered almost transparent in the wavelength region of $300-1000 \mathrm{~nm}^{42,43}$

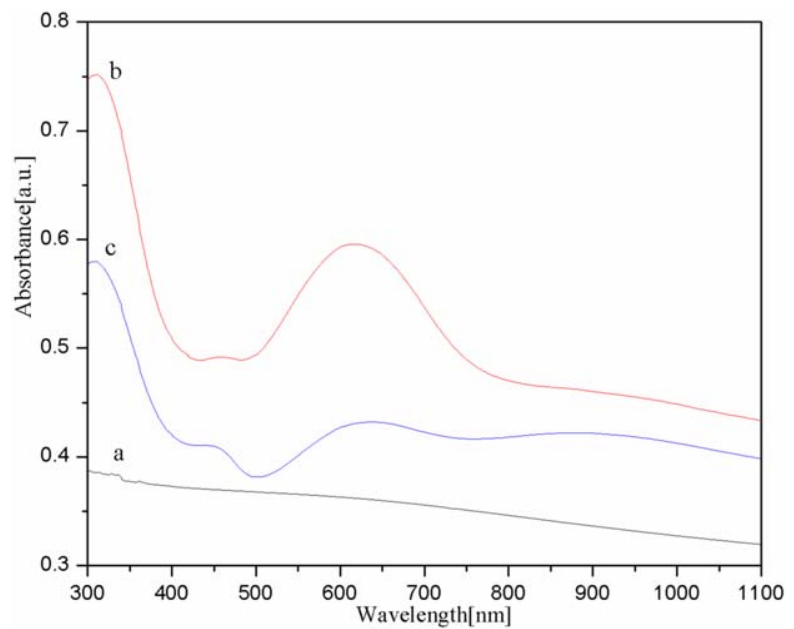

Figure 7. UV-vis spectra of (a) PLLA nanofiber mat, (b) PANI in DMF and (c) PLLA/PANI composite nanofiber mat. [Color figure can be viewed in the online issue, which is available at wileyonlinelibrary.com.] 
From Figure 7(b), one can see three characteristic bands for PANI at 310,458 , and $618 \mathrm{~nm}$, the first and the third bands can be attributed to the $\pi-\pi^{\star}$ transition of the benzenoid ring and exciton absorption of the quinonoid rings, respectively. The band at $458 \mathrm{~nm}$ can be assigned to polarn transition. ${ }^{40,44-46}$

The UV-vis spectrum of PLLA/PANI composite nanofiber mat [Figure 7(c)] shows the three absorbance bands of PANI at 310, $420 \rightarrow 465,632 \mathrm{~nm}$ with a slight shift, and additional broad band at $900 \mathrm{~nm}$ indicating that PANI is in its conducting state. ${ }^{8}$

\section{DC-Conductivity}

For DC conductivity $(\sigma), 30$ measurements were carried out for each of the 12 PLLA/PANI composite nanofiber mats prepared as mentioned above with 15 measurements on each side. $\sigma$ values were in the range of $0.07-0.13 \mathrm{~S} . \mathrm{cm}^{-1}$ with good homogeneity in $\sigma$ values for each film. We can attribute the difference in $\sigma$ values between different composite films to the accumulation of small process deviations committed during the preparation of each composite film from solutions preparation until the final product.

Comparing $\sigma$ values of these composite films with those reported for compressed pellets of PANI powder prepared with the same polymerization conditions, we find bigger $\sigma$ values in the range 4-6 S cm ${ }^{-1}$. ${ }^{47}$ We can attribute this difference to the high porosity of the non-woven mats and to the random orientation of the fibers in the composite mat which implicates a random movement of the charge carrier between electrodes. The electrical conductivity could also be affected by the morphology of $\pi$ conjugation polymers from respect of density of electrons and arrangement of PANI molecular chains in the composite mat. ${ }^{48}$

Comparing our $\sigma$ values with that of other composite nanofiber films produced by oxidative solution polymerization like poly(vinylchloride-acrylonitrile)/PANI composite nanofibers mats where $\sigma=2.2 \times 10^{-8} \mathrm{~S} \mathrm{~cm}^{-1},{ }^{20}$ and PMMA/PANI composite nanofiber mats where $\sigma \sim 10^{-6} \mathrm{~S} . \mathrm{cm}^{-1},{ }^{19}$ we find that our $\sigma$ values are many orders of magnitude bigger. We may attribute our high $\sigma$ values to the effectiveness of ultrasound stirring, used by us but not by the previous works, that allowed very good penetration of the monomer and the oxidant into the mat, so the PANI has completely shielded all the nanofibers of PLLA. In fact the SEM micrographs confirmed this assumption. To the best of our knowledge, the only bigger value than ours reported in the literature was for the composite nylon-6/PANI, ${ }^{22}$ and it was $\sigma=1.5 \mathrm{~S} \mathrm{~cm}{ }^{-1}$. It's one order of magnitude bigger than ours.

By comparing also our $\sigma$ values with the conductivity of electrospun nanofibers of PLLA blends with PANI where their conductivities are in the range $10^{-6} \rightarrow 10^{-9} \mathrm{~S} \mathrm{~cm}^{-1},{ }^{17,30,49}$ we can deduce that mats produced by oxidative solution polymerization of PANI onto PLLA nanofibers have higher conductivity than mats resulting from electrospinning of PLLA and PANI blends.

\section{CONCLUSION}

Conductive PLLA/PANI composite nanofiber mats were successfully prepared by bulk oxidative solution polymerization method of PANI onto PLLA nanofibers produced by electro- spinning of $6 \% \mathrm{w} / \mathrm{w}$ PLLA in dichloromethane solution with the presence of $1 \% \mathrm{w} / \mathrm{w}$ TBAB as an electrolyte. PLLA nanofibers were beads free with good shielding of PLLA nanofibers by PANI and with a good electrical conductivity. The PANI produced in this less harmful method is the standard emeraldine, without the need to distillate the monomer and with no need to further doping of the resulting polymer as the starting monomer is the powder of aniline hydrochloride.

\section{REFERENCES}

1. Skotheim, T. A.; Reynolds, J. R. Handbook of Conducting Polymers; CRC Press LLC: 2007, p 2.

2. Lange, U.; Mirsky, V. M. Anal. Chim. Acta 2011, 687, 105.

3. Valdés-Ramírez, G.; Windmiller, J. R.; Claussen, J. C.; Martinez, A. G.; Kuralay, F.; Zhou, M.; Zhou, N.; Polsky, R.; Miller, P. R.; Narayan, R. Sensor. Actuator. B: Chem. 2012, 161, 1018.

4. Ismail, Y. A.; Martínez, J. G.; Harrasi, A. S. A.; Kim, S. J.; Otero, T. F. Sensor. Actuator. B: Chem. 2011, 160, 1180.

5. Selvakumar, S.; Somanathan, N.; Reddy, K. A. Propellants, Explosives, Pyrotech. 2013, 38, 176.

6. Abdul Rahman, N.; Feisst, V.; Dickinson, M. E.; Malmström, J.; Dunbar, P.; Travas-Sejdic, J. Mater. Chem. Phys. 2013, 138, 333.

7. Blighe, F. M.; Diamond, D.; Coleman, J. N.; Lahiff, E. Carbon 2012, 50, 1447.

8. Mi, H.; Zhang, X.; Yang, S.; Ye, X.; Luo, J. Mater. Chem. Phys. 2008, 112, 127.

9. Huang, J. Pure Appl. Chem. 2006, 78, 15.

10. Zhang, Y.; Rutledge, G. C. Macromolecules 2012, 45, 4238.

11. Xing, S.; Zhao, C.; Jing, S.; Wang, Z. Polymer 2006, 47, 2305.

12. Zhang, X.; Goux, W. J.; Manohar, S. K. J. Am. Chem. Soc. 2004, 126, 4502.

13. Zhang, D.; Wang, Y. Mater. Sci. Eng. B 2006, 134, 9.

14. Huang, J.; Kaner, R. B. Angew. Chem. 2004, 116, 5941.

15. Huang, J.; Virji, S.; Weiller, B. H.; Kaner, R. B. J. Am. Chem. Soc. 2003, 125, 314.

16. Zhang, X.; Chan-Yu-King, R.; Jose, A.; Manohar, S. K. Synth. Met. 2004, 145, 23.

17. Abdul Rahman, N.; Gizdavic-Nikolaidis, M.; Ray, S.; Easteal, A. J.; Travas-Sejdic, J. Synth. Met. 2010, 160, 2015.

18. McKeon, K.; Lewis, A.; Freeman, J. J. Appl. Polym. Sci. 2010, $115,1566$.

19. Ji, S.; Li, Y.; Yang, M. Sensor. Actuator. B Chem. 2008, 133, 644.

20. Li, X.-Q.; Liu, W.-W.; Liu, S.-P.; Li, M.-J.; Li, Y.-G.; Ge, M.Q. Chinese Chem. Lett. 2014, 25, 83.

21. Chen, D.; Miao, Y.-E.; Liu, T. ACS Appl. Mater. Interfaces 2013, 5, 1206.

22. Hong, K. H.; Oh, K. W.; Kang, T. J. J. Appl. Polym. Sci. 2005, 96, 983. 
23. Prabhakaran, M. P.; Ghasemi-Mobarakeh, L.; Jin, G.; Ramakrishna, S. J. Biosci. Bioeng. 2011, 112, 501.

24. Patra, S.; Bhattacharyya, D.; Ray, S.; Easteal, A. IOP Conference Series: Mater. Sci. Eng. 2009, 4, 012020.

25. Liu, M.; Zhang, Y.; Zhou, C. Appl. Clay Sci. 2013, 75, 52.

26. Bognitzki, M.; Czado, W.; Frese, T.; Schaper, A.; Hellwig, M.; Steinhart, M.; Greiner, A.; Wendorff, J. H. Adv. Mater. 2001, 13, 70.

27. Picciani, P. H.; Medeiros, E. S.; Pan, Z.; Wood, D. F.; Orts, W. J.; Mattoso, L. H.; Soares, B. G. Macromol. Mater. Eng. 2010, 295, 618.

28. Gualandi, C.; Govoni, M.; Foroni, L.; Valente, S.; Bianchi, M.; Giordano, E.; Pasquinelli, G.; Biscarini, F.; Focarete, M. L. Eur. Polym. J. 2012, 48, 2008.

29. Han, M. G.; Lee, Y. J.; Byun, S. W.; Im, S. S. Synth. Met. 2001, 124, 337.

30. Prabhakaran, M. P.; Ghasemi-Mobarakeh, L.; Jin, G.; Ramakrishna, S. J. Biosci. Bioeng. 2011, 112, 501.

31. Mansor, M. K.; Ibrahim, N. A.; Yunus, W.; Ratnam, C. T. Malaysian Polym. J. 2011, 6, 165.

32. Trchová, M.; Stejskal, J. Pure Appl. Chem. 2011, 83, 1803.

33. Khuspe, G.; Navale, S.; Chougule, M.; Patil, V. Synth. Met. 2013, 185, 1.

34. Stejskal, J.; Exnerová, M.; Morávková, Z.; Trchová, M.; Hromádková, J.; Prokeš, J. Polym. Degrad. Stab. 2012, 97, 1026.

35. Nakayama, M.; Saeki, S.; Ogura, K. Anal. Sci. 1999, 15, 259.
36. Inai, R.; Kotaki, M.; Ramakrishna, S. Nanotechnology 2005, $16,208$.

37. Zong, X.; Kim, K.; Fang, D.; Ran, S.; Hsiao, B. S.; Chu, B. Polymer 2002, 43, 4403.

38. Garlotta, D. J. Polym. Environ. 2001, 9, 63.

39. Guo, H.; Zhu, H.; Lin, H.; Zhang, J. Matér. Lett. 2008, 62, 3919.

40. Jeevananda, T.; Lee, J. H. Matér. Lett. 2008, 62, 3995.

41. Zhang, Z.; Wei, Z.; Wan, M. Macromolecules 2002, 35, 5937.

42. Shameli, K.; Ahmad, M. B.; Yunus, W. M. Z. W.; Ibrahim, N. A.; Rahman, R. A.; Jokar, M.; Darroudi, M. Int. J. Nanomed. 2010, 5, 573.

43. Bocchini, S.; Frache, A. Exp. Polym. Lett. 2013, 7, 431.

44. Cho, M. S.; Park, S. Y.; Hwang, J. Y.; Choi, H. J. Mater. Sci. Eng. 2004, 24, 15.

45. Koul, S.; Chandra, R.; Dhawan, S. Polymer 2000, 41, 9305.

46. Babu, V. J.; Vempati, S.; Ramakrishna, S. Mater. Sci. Appl. 2013, 4, 1.

47. Stejskal, J.; Gilbert, R. Pure Appl. Chem. 2002, 74, 857.

48. Manivel, P.; Ramakrishnan, S.; Kothurkar, N. K.; Balamurugan, A.; Ponpandian, N.; Mangalaraj, D.; Viswanathan, C. Mater. Res. Bull. 2013, 48, 640.

49. Picciani, P. H.; Medeiros, E. S.; Pan, Z.; Orts, W. J.; Mattoso, L. H.; Soares, B. G. J. Appl. Polym. Sci. 2009, 112, 744. 